\title{
Physics centre head says he will follow Salam's example
}

Trieste. The International Centre for Theoretical Physics (ICTP) in Trieste, northern Italy, has completed its long search for a new director. Miguel Virasoro, a theoretical physicist born in Argentina, will next month take up the position vacated at the beginning of last year by the centre's founding director, Nobel prizewinner Abdus Salam.

Virasoro, who is 55, left Argentina in the mid-1970s, and took up a chair in theoretical physics at the University of Rome in 1982. A frequent visitor to the Trieste centre, he was chosen last month by the heads of the International Atomic Energy Agency (IAEA) and the United Nations Education, Scientific and Cultural Organization (UNESCO) from a short-list drawn up after the withdrawal of the sponsoring organizations' original choice, Praveen Chaudhari from IBM's Thomas Watson Research Center in New York (see Nature 373, 182; 1995).

Despite high hopes that the new director, like Chaudhari, should be from a developing country, the appointment of Virasoro, who now holds Italian citizenship, has been widely welcomed. "He is a first-class scientist," says ICTP's acting director, Luciano Bertocchi. But Virasoro will find he has a hard act to follow, as the whole shape of ICTP and, indeed, of science in Trieste - was moulded by Salam, who is still held in high esteem by the centre's staff.

ICTP was set up in 1964 under the auspices of the IAEA to train theoretical physicists from developing countries. From modest beginnings, the centre has grown enormously and now welcomes about 4,000 visiting scientists every year. It operates on an annual budget of more than US $\$ 20$ million, most of it provided by the Italian government.

Despite Trieste's relative isolation, the centre has helped to attract other scientific institutes to the city. Situated on the border with Slovenia, Trieste was once the major

\section{Corrections}

Claude Allègre was described in a news story on the French presidential elections as head of the Institut du Physique du Globe at the University of Paris VI (Nature 374, 666; 1995). Having occupied this post from 1976 to 1986 , he is now head of the department of geochemistry at the institute, and president of the Bureau de Recherches Géologiques et Minières. The current head of the institute, which is not part of the university, is Jean-Louis Le Mouël.

A recent news story on South Africa (Nature 374, 487; 1995) should have said that the science budget will be increased by 4.8 per cent next year, not 1.8 per cent. port of the Austro-Hungarian empire, but over the past century has lost both economic and political importance.

Despite a long tradition in the humanities - the city had no scientific tradition until the arrival of ICTP - it now host's Italy's only postgraduate school, the Scuola Internazionale Superiore di Studi Avanzati (SISSA), as well as the International Centre for Genetic Engineering and Biotechnology, and Elettra, a state-of-the-art synchrotron facility that began operation this year.

Salam also helped to set up three independent research centres - in materials, chemistry and environmental science under the auspices of the United Nations Industrial Development Organization (UNIDO). The core staff of these centres, which were launched in 1988, currently occupy the seventh floor of an ICTP building, known as "seventh heaven".

But without Salam's personal involvement, the original plan for the expansion of these centres, whose activities were intended to complement the more theoretical work of the ICTP, is unlikely to be put into effect. UNIDO wants the centres to become more industrially-oriented, as does the Italian government, which currently pays for them, but which would like industry to share the cost.

In recent years, ICTP's growth has created problems for the IAEA, which is concerned that the content of the centre's courses has extended well beyond the competence of the agency required to approve them. A few months ago, the Italian government agreed that responsibility for the administration of the centre be transferred to UNESCO - previously a junior partner - from next year.

The transfer has been welcomed by ICTP staff, in particular because it will result in better employment conditions. Under the IAEA, most staff contracts lasted just one year; now all staff will be on five-year renewable contracts. The new arrangement also transfers more administrative autonomy to the centre, increasing its direct control over its budget.

But it will also add to uncertainty over ICTP's future direction, as it is not yet known what influence UNESCO will want to have on the centre's range of activities. Virasoro says that he is keen to continue the tradition established by Salam, and told ICTP staff last week that he is not planning any changes in the centre's direction.

At least the long-term financial future looks secure. An Italian law passed in January guarantees the ICTP at least 20 billion lire (US\$11.8 million) a year until further notice. Before that, funding had only been secure up to 1998.

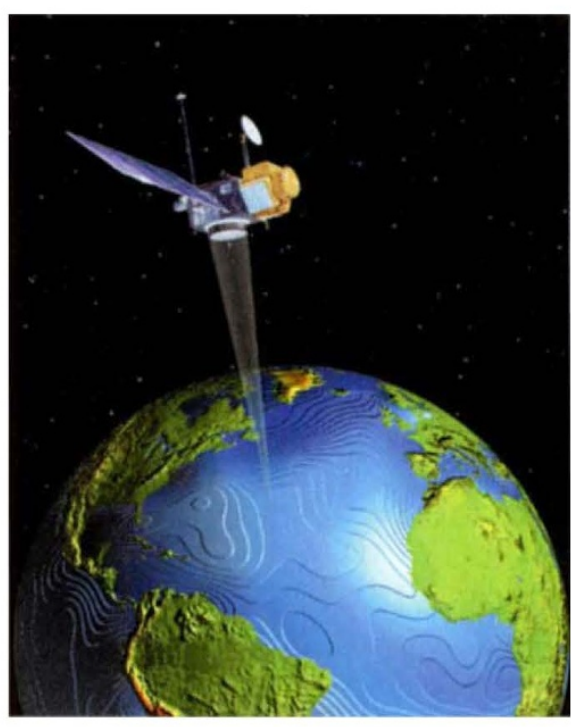

Topex: measuring the height of oceans.

\section{NASA 'to pick France' for ocean satellite}

Washington. The US National Aeronautics and Space Administration (NASA) is expected to choose a French-built radar altimeter rather than a US-manufactured instrument to fly as part of the agency's Earth Observing System (EOS) in 1999.

The altimeter, modelled on one launched on the US-French Topex-Poseidon spacecraft in 1992, is likely to be selected in preference to the US Navy's proposed Geosat Follow-On 2 (GFO-2) proposal. The two instruments provide similar information on sea-surface topography, and were similarly priced. But NASA officials have been keen to involve the French as partners on the EOS project.

William Townsend, deputy associate administrator for NASA's Mission to Planet Earth programme, says "the most important thing to us at this juncture [is] the international collaborative aspect". The TopexPoseidon follow-on option is expected to cost more than $\$ 300$ million, half the money coming from the French government.

A study by the National Academy of Sciences concluded that either of the GFO-2 or Topex/Poseidon instruments could meet the EOS project's needs if flown in the Topex orbit. In terms of science return, "one would be as good as the other", says Townsend.

In addition to providing EOS scientists with sea-surface data, the Topex-Poseidon altimeter will serve the US Navy as a backup to GFO-1, due to be launched next year.

In the event of an international conflict, the Navy has been assured that data from the instrument could be encrypted for security reasons. Townsend says they would still be made available to scientists, and that even though it would be on a slightly delayed basis, that would not affect the usefulness of the data for global change research.
Tony Reichhardt 